\title{
Public Credit Guarantee Schemes in Supporting SMEs: An Evaluation of Effectiveness and Impacts
}

\author{
Maria Cristina Arcuri ${ }^{1}$, Lorenzo Gai ${ }^{1} \&$ Federica Ielasi ${ }^{1}$ \\ ${ }^{1}$ Department of Economics and Management, University of Florence, Florence, Italy \\ Correspondence: Maria Cristina Arcuri, Department of Economics and Management, University of Florence, via \\ delle Pandette 9, 50127, Florence, Italy. E-mail: mariacristina.arcuri@unifi.it
}

Received: October 22, 2019

Accepted: December 11, 2019

Online Published: December 29, 2019

doi:10.5539/ijbm.v15n1p174

URL: https://doi.org/10.5539/ijbm.v15n1p174

\begin{abstract}
Public credit guarantee schemes are set up with the purpose of facilitating access to credit by Small and Medium-sized Enterprises (SMEs). The aim of the paper is to study the effectiveness and impacts of the Italian Central Guarantee Fund (CGF)'s activity, one of the main public guarantee schemes in Europe. This is even more important in the light of the 2018 CGF reform.

Analyzing a sample which includes all the guarantees issued by the CGF from 2012 to 2018 on loans made to manufacturing companies, we find that the CGF methodology is partially able to capture the variables affecting the probability of default of SMEs. The CGF scores before the reform show poor capability to forecast risk in the medium term, above all for micro and small enterprises. The post-reform model shows better forecasting ability and a greater consistency with the Z"-score, one of the most recognized model in the distress prediction literature. The new CGF model may indirectly control the behaviour of lenders and first-level guarantors. In particular, our findings show that the probability of default on exposures covered by a mutual guarantee institution and counter-guaranteed by the CGF is lower than the probability of default of loans granted by a bank and directly guaranteed by the CGF. As a consequence, the direct guarantees need to be more monitored by the CGF and potential effects on the bank behaviour may derive, strengthening ECB's supervision activities.
\end{abstract}

Keywords: banks, default risk, mutual guarantee institutions, public credit guarantee schemes, SMEs

\section{Introduction}

It is known that small firms, because of information asymmetry and adverse selection, frequently experience difficulties in accessing the credit market (Beck \& Demirguc-Kunt, 2006; Zaho, 2008). SMEs are often unable to provide information on their creditworthiness, and gathering information on SMEs can be challenging and costly for banks. This is particularly true for start-ups, given the level of uncertainty on the expected rates of return and the integrity of the borrower (Korosteleva and Mickiewicz, 2011).

Italy is an appropriate setting to study the topic. The Italian productive system consists largely of SMEs, which depend mainly on bank loans because of the undeveloped nature of financial markets (Ferri \& Messori, 2000).

The role of public guarantees is crucial in facilitating SME access to credit (OECD, 2016). In particular, the Central Guarantee Fund (CGF) supports SME access by issuing guarantees that complete or replace private ones. CGF is the main public credit guarantee program in Italy, and accounts for 2.1 percent of the GDP (European Investment Fund, 2014). CGF is managed by Mediocredito Centrale on behalf the Ministry of Economic Development. Its mission is to support access to credit by SMEs through direct guarantees to lending banks, or counter-guarantees to other credit guarantee institutions, mainly the Confidi (Italian mutually-based guarantee institutions). The CGF does not intervene in the relationship between the bank and the SME, but provides a public guarantee on financial operations. This guarantee can cover up to $80 \%$ of the loan, or up to $€ 2.5$ million, with the aim of improving the financial conditions applied to the borrowers by banks and Confidi (e.g. loan amount, required collateral, interest rate levels).

CGF applies to micro, small and medium enterprises (European Commission Recommendation 2003/361/CE) (Note 1) and has been active since 2000 (CGF, 2015). It has progressively increased its activity, with a big increase in recent years (Note 2). In 2018, CGF was reformed to include an internal credit rating model, similar to those developed by banks, and more accurate than the previous scoring system used for identifying eligible 
companies.

This paper contributes to the study of the effectiveness of the Italian guarantee program, which is one of the most important in Europe (OECD, 2016). The belief is that the criteria used to select firms are important because the impact on the economic system would be greater if the public funds were allocated efficiently. Moreover, the models implemented by the public guarantor can affect the moral hazard behaviours of banks and mutual guarantee institutions.

In particular, the aim of the paper is to analyse the financial sustainability of the CGF, given by the creditworthiness of the guaranteed companies. We distinguish the channel of the direct guarantee to banks and the channel of the counter-guarantee to Confidi. We investigate the relationship between variables relating to the operations (e.g., type of intervention, guaranteed amount) and to the individual SME (e.g. geographical area, size, financial ratios) and the default scores calculated using the same methodology as CGF. We also analyse the relationship between the same variables and the Z"-score (Altman et al., 2013), in order to verify whether the CGF model results are consistent with this widely used scoring methodology.

Our main research questions are the following: (1) Are the scores calculated following CGF assessment methodology able to capture the variables affecting SME default probability? (2) Does the probability of default of an SME (i.e. a score that approximates it) differ according to the type of CGF intervention? (3) Is the new CGF economic evaluation method more effective than the previous one for assessing the creditworthiness of SMEs and estimating their default risk?

We find that, although the original CGF methodology captures the variables affecting the SME probability of default, the new and more complex rating model brought in by the CGF reform is better able to assess the creditworthiness of SMEs. In particular, the new evaluation method seems to be better than the previous one when estimating the probability of default of guaranteed firms in the medium term in a more forward-looking approach. Since the score and, thus, the probability of default of SMEs, changes according to the type of CGF intervention (i.e. counter-guarantee or direct guarantee), the CGF reform should be able to indirectly control the behaviour of lenders and first-level guarantors, the Confidi.

The remainder of the paper proceeds as follows. In Section 2, we present a literature review and our main research hypotheses. In Section 3, we describe the data and methodology. In Section 4, we discuss the results and in Sections 5 and 6, we provide, respectively, a discussion and concluding comments with the managerial implications of our results.

\section{Literature Review and Research Hypotheses}

Public Credit Guarantee Schemes (PCGSs) are government-allocated funds set up to reduce banks' financial losses in cases of borrower default through the provision of direct guarantees or specific forms of co-guarantees or counter-guarantees. They are most common type of public intervention schemes in financial markets in both developing and developed countries (ADB-OECD, 2014; Asdrubali and Signore, 2015; KPMG, 2012; OECD, 2013). These schemes mainly aim to facilitate access to credit for specific types of firms - often SMEs or start-ups - which are particularly disadvantaged in terms of interest rate spreads and requested collateral (Berger and Udell, 2006; European Central Bank, 2018a; Leone and Vento, 2012; Levitsky, 1997; Riding et al., 2007; Zhang and Ye, 2010; Zecchini and Ventura, 2009). These constraints, exacerbated in recent years by economic and financial crises, have prompted many governments to ramp up existing structural guarantee instruments. Moreover, new guarantee programmes have been introduced to indirectly stimulate growth and job creation (Holton et al., 2013). Several authors (Beck et al., 2006; Cardone-Riportella et al., 2013; Gai et al., 2010; Gai and Ielasi, 2014) report that banks consider PCGSs the most common and effective government support programmes for SME lending, ahead of directed credit and interest rates or subsidised loans.

Our research aims to assess the level of financial sustainability of public intervention in relation to the potential risk of losses of public funds. The field of financial sustainability of governmental programmes is especially urgent today, given the strong growth in the scale and scope of PCGSs internationally.

In general, access to credit is instrumental to economic development and poverty reduction. The PCGSs pursue this aim by offering risk mitigation to lenders by taking a share of the lenders' losses on SME loans in the case of default. This does not mean, however, that access to credit becomes a universal right as a result of its potential negative effects, including overindebtedness (Hudon, 2009). In fact, the SMEs guaranteed by the CGF have a low credit rating but are assessed as being economically and financially sound (CGF, 2015). A public guarantee scheme can maintain sustainability if it provides proper incentives to financial intermediaries for making an effective assessment of firms' creditworthiness. As the guarantor of last resort, the government assumes risk for loans granted and guaranteed by other financial institutions which may potentially follow moral hazard behaviours, which is particularly common when the assessment of default risk and the associated risk taking are separated (Boot and Thakor, 1994; Bubb and Kaufman, 2009; Hartman-Glaser et al., 2012; Jemenez and Saurina, 
2004).

In order to evaluate the financial sustainability of CGF, we refer to the international field of study focused on predicting bankruptcy using statistics and economic-financial indicators. The first studies date back to the 1930s (FitzPatrick, 1932; Ramser and Foster, 1931; Smith and Wina, 1935) when many models were developed to facilitate creditworthiness assessment by banks. In subsequent years, other researchers concentrated on using economic-financial indicators for prediction purposes (see, among others, Altman, 1968, 1983; Aziz et al., 1988; Beaver, 1966; Edmister, 1972; Hillegeist et al., 2004; Ohlson, 1980; Riding and Haines, 2001; Shumway, 2002; Tamari, 1966) (Note 3).

The original Altman Z-score (Altman, 1968), because of its ability to predict and its easy application, is one of the best-known distress prediction models. It originally identified four balance sheet and income statement variables and a stock market variable, concerning liquidity, profitability, leverage, solvency and activity, useful for predicting the bankruptcy likelihood of companies. On the first application, the model was extremely accurate and the percentage of correct predictions was about 95\%. It received positive feedback and little criticism (Johnson, 1970). The model has been revised by its author over time (Altman, 1983; Altman, 2002). The parameters have been constantly updated and the indices have been adapted for other samples of companies and not only companies listed on the American stock exchange. The Z'-score (Altman, 1983) is an adaptation for private companies. The Z"-score (Altman et al., 1995; Altman and Hotchkiss, 2006) was introduced for the non-manufacturing and manufacturing sectors or companies operating in developing countries. Altman et al. (2013) also identified the appropriate Z-score for Italian manufacturing companies subject to Extraordinary Administration [EA under Decreto Legislativo 270/1999 and Decreto Legge 347/2003] during the period 2000 to 2010. They found that the Z"-score prediction tool is the most suitable in the light of the relationship between Italian firms and banks. The Z" score, according to this literature, is an effective tool for forecasting firm bankruptcy like hood, and can be used for evaluating their creditworthiness.

In order to verify the level of effectiveness of CGF model pre-reform in forecasting SME default risk we test the following first hypothesis:

H1: Prior to the recent reform, CGF's evaluation of SMEs' default risk was consistent with Z'-score prediction.

Once the effectiveness of the pre-reform CGF model is verified, we test the improvements in forecasting capability by analyzing the results of the new methodology (i.e. post-reform) taking into account operational experience gained by the CGF in recent years. In particular, we verify whether the new model, applied to companies which successfully obtained a guarantee in the past, would have better identified the SMEs with a negative financial trend in the future, operating a better selection at the beginning thanks to a more forward-looking approach.

We aim therefore to test the following second hypothesis:

H2: The predictive capability of CGF methodology is higher in the post-reform credit rating model than the previous model.

Among studies on the effectiveness of public intervention in guaranteeing loans, one strand of literature focuses on the advantages of counter-guarantee schemes, for both the guarantors (Confidi and Government) and companies. Importantly, empirical studies show that the possibility of obtaining a public counter-guarantee has helped increase the volume of Confidi's mutual guarantees and improved the credibility and reputation of private guarantee schemes, even during the most intense periods of crisis (European Commission, 2005; AECM, 2010). Moreover, Confidi guarantees generate a significant leverage effect on private guarantee schemes, contributing to their sustainability and permanence (Beck et al., 2008). The CGF leaves only a small part of the risk to the first-level guarantor, which allows Confidi to increase operational activity without increasing risk. From the public perspective, a counter-guarantee does not imply an immediate negative cash flow for the government, because the payment is effective only when main guarantor enforces the counter-guarantee in the event of borrower default (Arping et al., 2010; Honohan, 2008). In terms of impact on SMEs, a counter-guarantee offered to a Confidi produces a higher multiplier of the access to credit opportunities than a direct guarantee offered to a bank. In fact, for a particular amount of public funds, the number of assisted firms is higher where there are counter-guarantees than where there are direct guarantees, because a part of the risk continues to be allocated to the first-level guarantor (Erzegovesi, 2009). Moreover, firms affiliated to a Confidi pay a lower interest rate for loans. Confidi in fact appear to be better able to carry out peer screening and monitoring than banks (Columba, 2010; Mistrulli \& Vacca, 2011). Bartoli et al. (2013) find that Italian firms assisted by Confidi are less likely to experience financial distress. They also find that the positive effect of a Confidi guarantee is higher for SMEs with a shorter bank relationship length. However, the Confidi may be characterized by an adverse selection problem. Confidi are in fact likely to attract risky firms because low risk companies may not wish to share the risk borne by other companies in becoming part of a mutual guarantee scheme. Some studies (e.g., Banca d'Italia, 
2017) highlight that firms with a mutual Confidi guarantee are characterized, ceteris paribus, by a higher level of default risk than similar SMEs without a mutual guarantee.

In the light of the varied findings in the literature, we test the following hypothesis:

H3: The probability of loan default (i.e. a score that approximates default) for loans directly guaranteed by CGF is lower than the probability of default on counter-guaranteed loans.

\section{Empirical Research}

\subsection{Data}

We analyse an initial sample of 502 financial operations (i.e. the issue of a guarantee to a single firm) taking place from the third quarter 2012 to the second quarter 2018. They represent the whole universe of operations made by the CGF in that period on the request of manufacturing firms. We focus on manufacturing because it is the economic sector with the highest number of applications accepted and firms guaranteed in recent years (Source: CGF, 2019).

We analyse data useful for predicting the default risk of the borrower, related to the loan (e.g., amount of the loan); to the guarantee (e.g. date granted, type of CGF intervention); and to the SMEs (e.g. geographical area, size, financial ratios). We also consider macroeconomic variables, such as the Gross Domestic Product (GDP) and the unemployment rate. Data are sourced from an original database made available by the CGF and the Bureau van Dijk AIDA database. To be included in our sample, financial ratios and balance sheet and financial income data had to be available in the last database. Moreover, we conduct our investigation by considering the balance sheet and income statement of SMEs from the previous year $(t-1)$ and the two years following the CGF operation $(t+2)$. Operations from 2017 to 2018 are therefore excluded. Our final sample includes 400 CGF operations of which 200 are counter-guarantees to Confidi and 200 are direct guarantees to lending banks.

As is well known, the financial structure of firms changes according to their size. We distinguish firms between micro-sized firms having 10 employees at most, small-sized firms having between 11 and 50 employees and medium-sized firms having between 51 and 250 employees (European Commission Recommendation 2003/361/CE). Micro and small firms have simpler financial structures and benefit more from the support of the CGF than those of a larger size. Our sample includes, in fact, 84 operations with micro firms $(21 \%$ of the sample), 269 with small firms (67.25\% of the sample), and 47 with medium firms (11.75\% of the sample). Medium size firms can access alternative sources of funding (e.g. equity and retained earnings).

Table 1 summarizes the descriptive statistics of the sample analysed, with reference to year $t$ (i.e. the year when the guarantee was issued) (Note 4). Consistently with the literature on SME access to finance (De Jong et al., 2008; Hall et al., 2004, Lawless et al., 2015; Libby, 1995; Psillaki and Daskalakis, 2009), our independent variables measure the following firm performance factors: profitability, liquidity, solvency and financial structure. We also consider size (number of employees) and geographical area (north, central and south Italy) of the guaranteed firms.

Table 1. Descriptive statistics (manufacturing sector, year $t$ )

\begin{tabular}{lllll}
\hline Independent variable & Mean & Std. Dev. & Min & Max \\
\hline Guaranteed amount/Loan amount & 0.60 & 0.164 & 0.04 & 0.80 \\
Liquidity index & 0.80 & 0.422 & 0.05 & 6.23 \\
Debt to equity ratio & 9.49 & 9.851 & -6.46 & 51.03 \\
Return on Sales (ROS) & 4.44 & 4.340 & -33.66 & 17.19 \\
Return on Equity (ROE) & 8.02 & 20.873 & -114.88 & 87.60 \\
Number of employees & 29.63 & 32.839 & 1 & 215 \\
Unemployment rate & 9.40 & 3.427 & 4.90 & 22.17 \\
Gross Domestic Product (GDP) & $145,436.05$ & $78,272.17$ & $11,254.30$ & $353,993.50$ \\
\hline
\end{tabular}

Note. The table presents descriptive statistics for 400 financial guarantees made from the third quarter 2012 to the second quarter 2018 to manufacturing SMEs. Data are related to the year when the guarantee was issued.

\subsection{Methodology}

The analysis is carried out on the scores calculated using CGF assessment methodology. This study also focuses on applying the most appropriate Z-score model, according to the company sector. The original Z-score (Altman, 1968) involved a group of American manufacturing companies quoted on the Stock Market. The Z'-score 
(Altman, 1983) was an adaptation for private companies. The five indicators in the two Altman manufacturing firm versions are listed in Table 2, which also shows the linear relationship between variables.

Table 2. Altman Z- score and Z'score models

\begin{tabular}{ll}
\hline$Z$-score (1968) & $Z^{\prime}$-score (1983) \\
\hline $\mathrm{X}_{1}=$ Working Capital/Total Assets & $\mathrm{X}_{1}=$ Working Capital/Total Assets \\
$\mathrm{X}_{2}=$ Retained Earnings/Total Assets & $\mathrm{X}_{2}=$ Retained Earnings/Total Assets \\
$\mathrm{X}_{3}=$ EBIT/ Total Assets & $\mathrm{X}_{3}=$ EBIT/ Total Assets \\
$\mathrm{X}_{4}=$ Market Value Equity/Book Value of Total Debt & $\mathrm{X}_{4}=$ Book Value Equity/Total liabilities \\
$\mathrm{X}_{5}=$ Sales/ Total Assets & $\mathrm{X}_{5}=$ Sales/ Total Assets \\
Linear regression & Linear regression \\
$\mathrm{Z}=1.2 \mathrm{X}_{1}+1.4 \mathrm{X}_{2}+3.3 \mathrm{X}_{3}+0.6 \mathrm{X}_{4}+0.999 \mathrm{X}_{5}$ & $\mathrm{Z}=0.717 \mathrm{X}_{1}+0.847 \mathrm{X}_{2}+3.107 \mathrm{X}_{3}+0.420 \mathrm{X}_{4}+0.998 \mathrm{X}_{5}$ \\
\hline
\end{tabular}

Source: Altman (1968 \& 1983).

During subsequent years, parameters and coefficients were adapted for different situations. The Z"-score (Altman et al., 1995; Altman and Hotchkiss, 2006) was introduced for the non-manufacturing as well as manufacturing sectors, and companies operating in developing countries. The variables of the Z"-score were the same as the $Z$ ' -score model with the exclusion of the sales/total assets, activity ratio $\left(\mathrm{X}_{5}\right)$ in order to filter the function from the possible distortion related to the sector and country. The weighted coefficients thus have different values:

$$
\mathrm{Z} "=6.56 \mathrm{X}_{1}+3.26 \mathrm{X}_{2}+6.72 \mathrm{X}_{3}+1.05 \mathrm{X}_{4}
$$

Altman et al. (2013) focused on applying the most appropriate Z-score model to Italian manufacturing companies subject to Extraordinary Administration (EA under Decreto Legislativo 270/1999 and Decreto Legge 347/2003) between 2000 and 2010. They find that the Z"'-score prediction tool is more suitable for the Italian context than the $Z$ '-score, in the light of the long-standing relationship between Italian firms and banks. In fact, although Italian firms may appear distressed from a statistical point of view, it is probable that they are in reality benefitting from the support of banks, and owners have often preferred to leverage their companies in order to profit from fiscal advantages. This phenomenon however is no longer as pervasive as it was in 2012, as many banks in Italy are struggling due to capital shortages. Finally, it has been shown that the Z"'-score model applied to non-US companies is far more robust than Altman's other models (Altman and Hotchkiss, 2006).

In order to verify the trend of the default risk for the SMEs guaranteed, we analyse the variation in Z"-score and CGF pre-reform score one year and two years after the date of guarantee issue. Later, we observe the post-2018 reform CGF scoring model to verify whether it is able to better discriminate SMEs at higher default risk than the original scoring model.

Before the recent reform, CGF considered the ratios shown in Table 3 relating to the last two balance sheets and income statements in order to evaluate the creditworthiness of manufacturing SMEs (Table 3).

Table 3. CGF pre-reform financial ratios included in the scoring system

Source: CGF (2015)

\begin{tabular}{ll}
\hline Financial ratio & Reference value \\
\hline A) (Equity + Long-term Debt)/Total fixed assets & $\geq 100 \%$ \\
B) Equity/Total liabilities & $\geq 10 \%$ \\
C) EBITDA/Financial expenses & $\geq 2$ \\
D) EBITDA/Sales & $\geq 8 \%$ \\
\hline
\end{tabular}

On the basis of the reference values of the ratio, the following scores are assigned to the SMEs (Table 4). 
Table 4. CGF pre-reform scoring system

\begin{tabular}{ll}
\hline Value & Score \\
\hline "A" $\geq 100 \%$ & 3 \\
$50 \%<" \mathrm{~A} "<100 \%$ & 2 \\
$0<" \mathrm{~A} " \leq 50 \%$ & 1 \\
"A" $\leq 0$ & 0 \\
"B" $\geq 10 \%$ & 3 \\
$6 \%<" \mathrm{~B} "<10 \%$ & 2 \\
$0<" \mathrm{~B} " \leq 6 \%$ & 1 \\
"B" $\leq 0$ & 0 \\
"C" $\geq 2$ & 3 \\
$2>$ "C" $\geq 1.5$ & 2 \\
$1.5>$ "CC" $\geq 1$ & 1 \\
"C" $<1$ & 0 \\
"D" $\geq 8 \%$ & 3 \\
$8 \%>$ "D" $\geq 5 \%$ & 2 \\
$5 \%>$ "D" $\geq 3 \%$ & 1 \\
"D"<3\% & 0 \\
\hline
\end{tabular}

Source: CGF (2015).

The total score for each company varies between a minimum of 0 points and a maximum of 12 points. Companies are divided into three levels to which different evaluation ranges correspond.

Since the 2018 reform, CGF has calculated the basic score in order to evaluate the creditworthiness of manufacturing SMEs as follows:

$$
\mathrm{Xb}_{\mathrm{SDC} ; \mathrm{SDPDI}}=\mathrm{COST}+\sum_{i=1}^{n} \quad \mathrm{x}_{\mathrm{i}} * \mathrm{~b}_{\mathrm{i}}
$$

Where:

cost $=$ constant

$\mathrm{x}_{\mathrm{i}}=$ variable

$\mathrm{b}_{\mathrm{i}}=$ coefficient.

CGF assesses the economic and financial situation of manufacturing SMEs by considering the variables shown in Table 5 (including dummy variables - D). These variables are "treated" ( $\mathrm{V}^{*}$ ) by attributing cap and floor.

Table 5. CGF post 2018 reform financial ratios used in the scoring system

\begin{tabular}{llll}
\hline Variables & Description & Variables $\left(\mathrm{x}_{\mathrm{i}}\right)$ & Coefficient \\
\hline V1 & Short-term debt/Sales & $\mathrm{V}_{1}{ }^{*}$ & 1.709764 \\
V2 & Financial expenses/EBITDA & $\mathrm{V}_{2}{ }^{*}$ & 1.006155 \\
D1 & Financial expenses/EBITDA (downside) & $\mathrm{D}_{1}$ & -1.380646 \\
D2 & EBITDA (downside) & $\mathrm{D}_{2}$ & 0.52537 \\
V3 & Cost of debt & $\mathrm{V}_{3}{ }^{*}$ & 21.7339 \\
V4 & Cash/Sales & $\mathrm{V}_{4}{ }^{*}$ & -3.257383 \\
V5 & Inventory turnover & $\mathrm{V}_{5}{ }^{*}$ & -0.035931 \\
V6 & Percentage change in Sales & $\mathrm{V}_{6}{ }^{*}$ & 0.874921 \\
V7 & Book value/Total Assets & $\mathrm{V}_{7}{ }^{*}$ & -1.842869 \\
D3 & Percentage change in Sales (downside) & $\mathrm{D}_{3}$ & -1.318575 \\
D4 & Sales volume & $\mathrm{D}_{4}$ & 0.925375 \\
D5 & Short-term debt/Sales (for sales volume) & $\mathrm{D}_{5}$ & -0.672704 \\
D6 & Cost of debt (for sales volume) & $\mathrm{D}_{6}$ & -11.51058 \\
D7 & Cash/Sales (for sales volume) & $\mathrm{D}_{7}$ & 1.934049 \\
& & $\mathrm{Constant}_{2}$ & -4.584023 \\
\hline
\end{tabular}

Source: Banca del Mezzogiorno-Medio Credito Centrale (2018). 
Each class as revealed by the score is assigned an evaluation from 1 to 12 . The 12 evaluation classes are then grouped into 5 evaluation ranges. The fifth evaluation range, which includes the highest valuation classes, corresponds to the highest probability of default (i.e. the highest values of the score). It is important to note at this point that score calculation is only one part of the CGF process of default assessment. The full process also includes an economic-financial module and a module based on data supplied by the Italian Central Credit Register and Credit Bureau.

Once the scores approximating the probability of default of the manufacturing firms are calculated, we consider their trend over the period from $t-1$ to $t+2$ and apply a multiple linear regression estimated using ordinary least squares (OLS) on our cross-sectional data to identify the variables capturing the risk. Equation (3) summarizes our model.

$$
\mathrm{Y}_{\mathrm{i}, \mathrm{t},(\mathrm{t}-1),(\mathrm{t}+\mathrm{n})}=\beta_{0}+\beta_{1} \mathrm{x}_{1 \mathrm{i}, \mathrm{t},(\mathrm{t}-1),(\mathrm{t}+\mathrm{n})}+\ldots+\beta_{\mathrm{k}} \mathrm{x}_{\mathrm{kit},(\mathrm{t}-1),(\mathrm{t}+\mathrm{n})}+\varepsilon_{\mathrm{i}}
$$

where: Y is the Z"'-score, the CGF pre-reform score (Score 1) and post-reform score (Score 2) for operation $i$ at time $t, t-1, t+n$, where $\mathrm{n}$ is equal to 1 and $2 ; \mathrm{x}_{1 \mathrm{i}}, \ldots, \mathrm{x}_{\mathrm{ki}}$ are the independent variables, with $i=1,2, \ldots, \mathrm{n}$. Independent variables are those shown in Table 1 plus a set of dummies relating to the type of intervention, the geographical area and the size of firms. Consistently with CGF methodology all variables are lagged; this makes it possible to control for endogeneity problems. $\varepsilon_{\mathrm{i}}$ is an error term.

The regression is first run on the whole sample over the whole period (from $t-1$ to $t+2$ ) and secondly on three different periods $(t, t+1$ and $t+2)$ separately.

\section{Results}

Our first results are reported in Table 6, which shows the significant results for Z'"-Score, CGF pre-reform score (Score 1) and CGF post-reform score (Score 2). As described above, we consider the variation of scores from one year to the next during the period $t-1$ to $t+2$.

Table 6. Estimation of the $\Delta \mathrm{Z}$ "-Score, $\Delta$ Score 1 and $\Delta$ Score $2(t-1$ to $t+2)$

\begin{tabular}{lcll}
\hline \multicolumn{4}{c}{ Dependent variable } \\
\hline Independent variables & $\Delta Z^{\prime \prime}$-Score & $\Delta$ Score 1 & $\Delta$ Score 2 \\
\hline Constant & -0.70579 & 0.14436 & -0.04350 \\
Type of intervention (counterguarantee) & -0.17488 & $0.07763^{* * *}$ & $-0.04784^{* *}$ \\
Guaranteed amount/Loan amount & -0.36995 & $0.16022^{* *}$ & $-0.10876^{*}$ \\
North & 0.34445 & $-0.19302^{* * *} 0.09979^{*}$ \\
Central & 0.96000 & $-0.1524^{* *}$ & -0.01246 \\
Liquidity index & $0.41434^{* *}$ & -0.00712 & -0.00172 \\
Debt to equity ratio & $-0.06503^{* * *}-0.00432^{*}$ & $0.00503^{* *}$ \\
ROS & -0.03769 & 0.00271 & $-0.00448^{* *}$ \\
ROE & $0.01063 * *$ & -0.0001 & $-0.0009 * *$ \\
Micro & 0.46429 & -0.03771 & 0.04108 \\
Small & 0.14202 & -0.01668 & 0.00499 \\
Unemployment rate & 0.02786 & $-0.01452^{* * *} 0.00604$ \\
GDP & 0.00001 & $0.00002^{*}$ & 0.00001 \\
Adjusted R-squared & 0.01333 & 0.03013 & 0.05629 \\
Obs. & 400 & 400 & 400 \\
\hline
\end{tabular}

Note. The table reports the estimation of the $\Delta Z$ "-score, $\Delta$ CGF pre-reform ( $\Delta$ Score 1) and post-reform score ( $\Delta$ Score 2$)$ during the period starting from the year before the guarantee is issued $(t-1)$ to two years after it $(t+2)$. The significance is expressed with one, two or three asterisks, i.e. the rejection of the hypothesis of values equivalent to 0 with a probability level equal to $10 \%, 5 \%$ or $1 \%$. 
First, we specify that for the Z' '-score and Score 1, the higher the value, the lower the probability of default, and vice versa in the case of Score 2. Our results confirm that the scores capture the main variables affecting the probability of default of SMEs. The change in Z' -score during the period from $t-1$ to $t+2$ is mainly due to the levels of liquidity (i.e. liquidity ratio), solvency (i.e. debt to equity ratio) and profitability of firms (i.e. ROS and ROE). Only the debt to equity ratio, showing the percentage of company financing that comes from creditors and investors (i.e. the financial structure of the firm), explains the change in Score 1 over time. The results referring to Score 2 confirm most of those related to the Z' -score: the solvency and profitability levels of firms are significant variables.

The geographical area where the guaranteed firms operate and some variables related to the operations (i.e. the amount guaranteed and the type of intervention) are also significant. In particular, guaranteed SMEs in the north of Italy included in our sample appear to be riskier than companies located elsewhere in Italy in the overall period $t-1$ to $t+2$. Moreover, the greater the amount guaranteed in relation to the loan amount, the lower the probability of default.

We also find that the probability of default of SMEs differs according to the type of CGF intervention. Consistently with previous research (Columba et al., 2010; Mistrulli and Vacca, 2011) which identified better peer screening and monitoring by Confidi than by banks, our results show that counter guarantees requested by Confidi are characterized by a probability of default lower than direct guarantees requested by banks.

Finally, macroeconomics variables (i.e., regional unemployment rate and GDP) are significant only when the probability of default is approximated by Score 1 .

Since we aim to analyse the effectiveness and sustainability over time of the Italian guarantee program, we examine the variation of the scores after one and after two years from when the guarantee is issued. Tables 7, 8 and 9 show the results.

Table 7. Estimation of the $\Delta \mathrm{Z}$ "-score (year $t, t+1$ and $t+2$ )

\begin{tabular}{|c|c|c|c|}
\hline \multirow[b]{2}{*}{ Independent variables } & \multicolumn{3}{|c|}{ Dependent variable: $\Delta Z$ "-score } \\
\hline & $t$ & $t+1$ & $t+2$ \\
\hline Constant & -2.12878 & 1.24323 & 5.36355 \\
\hline Type of intervention (counterguarantee) & 0.318206 & 111225 & \\
\hline Guaranteed amount/Loan amount & -0.91771 & $\begin{array}{r}-1.11225 \\
0.73511\end{array}$ & \\
\hline North & 1.39464 & -0.15311 & \\
\hline Central & 0.54144 & -0.98150 & 0.28027 \\
\hline Liquidity inde $\mathrm{x}_{\mathrm{t}+2}$ & & 1.94736 & -0.50603 \\
\hline Liquidity inde $x_{t+1}$ & & & $4.93770^{* *}$ \\
\hline Liquidity inde $x_{t}$ & $0.63845 * *$ & 0.47847 & $4.60975^{* *}$ \\
\hline Debt to equity ratio $\mathrm{t}_{\mathrm{t}+2}$ & & & $2.04629 * * *$ \\
\hline Debt to equity ratio ${ }_{t+1}$ & & $012708 * *$ & \\
\hline Debt to equity ratio ${ }_{t}$ & -0.04165 & $-0.13298^{* *}$ & (007908 \\
\hline $\operatorname{ROS}_{\mathrm{t}+2}$ & & & -0.02990 \\
\hline $\operatorname{ROS}_{\mathrm{t}+1}$ & & -0.03784 & \\
\hline $\operatorname{ROS}_{t}$ & -0.05702 & & $0.10288^{* *}$ \\
\hline $\mathrm{ROE}_{\mathrm{t}+2}$ & & & \\
\hline $\mathrm{ROE}_{\mathrm{t}+1}$ & & $0.02209 *$ & \\
\hline $\mathrm{ROE}_{t}$ & 0.00736 & & -0.09432 \\
\hline Micro & -0.39440 & & \\
\hline Small & -0.21723 & $\begin{array}{l}1.94402 \\
0.72957\end{array}$ & \\
\hline Unemployment rate $_{t+2}$ & & & 0.18209 \\
\hline Unemployment rate $_{t+1}$ & & 007033 & $13635 * *$ \\
\hline Unemployment rate $_{t}$ & 0.13467 & 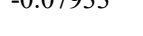 & 1.15055 \\
\hline $\mathrm{GDP}_{\mathrm{t}+2}$ & & & $-0.34432^{2 *}$ \\
\hline $\mathrm{GDP}_{\mathrm{t}+1}$ & & 0.00003 & \\
\hline $\mathrm{GDP}_{\mathrm{t}}$ & -0.00003 & & \\
\hline Adjusted R-squared & 0.00924 & 0.05149 & 0.20572 \\
\hline Obs. & 400 & 400 & 400 \\
\hline
\end{tabular}

Note. The table reports the estimation of the $\Delta Z$ "-score in the year $t$ (when CGF issued the guarantee), $t+1$ (one year after it) and $t+2$ (two years after it). The significance is expressed with one, two or three asterisks, i.e. the rejection of the hypothesis of values equivalent to 0 with a probability level equal to $10 \%, 5 \%$ or $1 \%$. 
Table 8. Estimation of $\Delta$ Score 1 (year $t, t+1$ and $t+2$ )

\begin{tabular}{|c|c|c|c|}
\hline \multirow[b]{2}{*}{ Independent variables } & \multicolumn{3}{|c|}{ Dependent variable: $\Delta$ Score 1} \\
\hline & $t$ & $t+1$ & $t+2$ \\
\hline Constant & 0.17465 & -0.59413 & -0.52701 \\
\hline Type of intervention (counterguarantee) & 0.02857 & $0.07586^{*}$ & \\
\hline Guaranteed amount/Loan amount & $0.17450 * *$ & $0.08223 *$ & 0.09056 \\
\hline North & $-0.21832 * *$ & $0.28974^{* *}$ & -0.20213 \\
\hline Central & $-0.21112^{* * *}$ & $0.28943^{* *}$ & 0.26406 \\
\hline Liquidity index $\mathrm{x}_{\mathrm{t}+2}$ & & & 0.29490 \\
\hline Liquidity inde $x_{t+1}$ & & -0.00912 & $0.15729 * *$ \\
\hline Liquidity index $x_{t}$ & 0.00806 & & \\
\hline \multicolumn{4}{|l|}{ Debt to equity ratio $\mathrm{t}_{+2}$} \\
\hline Debt to equity ratio $\mathrm{t}_{t+1}$ & & -0.00076 & 0.00642 \\
\hline Debt to equity ratio ${ }_{t}$ & $-0.01446^{* * *}$ & & \\
\hline \multicolumn{4}{|l|}{$\operatorname{ROS}_{\mathrm{t}+2}$} \\
\hline $\operatorname{ROS}_{t+1}$ & & $0.00686^{* *}$ & 0.00217 \\
\hline $\operatorname{ROS}_{t}$ & $0.00952 * * *$ & & \\
\hline \multicolumn{4}{|l|}{$\mathrm{ROE}_{\mathrm{t}+2}$} \\
\hline $\mathrm{ROE}_{\mathrm{t}+1}$ & & 0.00099 & -0.00070 \\
\hline $\mathrm{ROE}_{\mathrm{t}}$ & -0.00069 & & \\
\hline Micro & 0.02728 & -0.04916 & \\
\hline Small & -0.00597 & 0.01801 & 0.00254 \\
\hline Unemployment rate $_{\mathrm{t}+2}$ & & & 0.02127 \\
\hline Unemployment rate $_{t+1}$ & & $-0.02221 * *$ & 0.02383 \\
\hline Unemployment rate $_{t}$ & $-0.02098^{* * *}$ & & \\
\hline \multicolumn{4}{|l|}{$\mathrm{GDP}_{\mathrm{t}+2}$} \\
\hline $\mathrm{GDP}_{\mathrm{t}+1}$ & & $0.00001 *$ & 0.00001 \\
\hline $\mathrm{GDP}_{\mathrm{t}}$ & 0.00001 & & \\
\hline Adjusted R-squared & 0.21197 & 0.03604 & 0.01875 \\
\hline Obs. & 400 & 400 & 400 \\
\hline
\end{tabular}

Note. The table reports the estimation of the $\Delta$ Score 1 in the year $t$ (when CGF issued the guarantee), $t+1$ (after one year) and $t+2$ (after two years). The significance is expressed with one, two or three asterisks, i.e. the rejection of the hypothesis of values equivalent to 0 with a probability level equal to $10 \%, 5 \%$ or $1 \%$.

Table 9. Estimation of $\Delta$ Score 2 (year $t, t+1$ and $t+2$ )

\begin{tabular}{|c|c|c|c|}
\hline \multirow[b]{2}{*}{ Independent variables } & \multicolumn{3}{|c|}{ Dependent variable: $\Delta$ Score 2} \\
\hline & $t$ & $t+1$ & $t+2$ \\
\hline Constant & $-0.71855^{* * *}$ & $0.70393 * * *$ & $-1.288644 * * *$ \\
\hline Type of intervention (counterguarantee) & $-0.10528^{* *}$ & 0.01134 & $-0.12378 * *$ \\
\hline Guaranteed amount/Loan amount & -0.12552 & $-0.01214^{*}$ & $-0.17907^{*}$ \\
\hline North & $0.46362 * * *$ & $-0.32450^{* * *}$ & $0.48541^{* *}$ \\
\hline Central & $0.34847 * * *$ & $-0.52187 * * *$ & $0.44612 * *$ \\
\hline Liquidity index $\mathrm{t}_{\mathrm{t}+2}$ & & & 0.07337 \\
\hline Liquidity index $\mathrm{x}_{\mathrm{t}+1}$ & & -0.01525 & \\
\hline Liquidity inde $x_{t}$ & -0.02134 & & \\
\hline Debt to equity ratio $\mathrm{t}_{\mathrm{t} 2}$ & & & $0.01229^{* * *}$ \\
\hline Debt to equity ratio $\mathrm{t}_{t+1}$ & & $0.01005^{* * *}$ & \\
\hline Debt to equity ratio $t$ & 0.00041 & & \\
\hline $\operatorname{ROS}_{\mathrm{t}+2}$ & & & $-0.01555^{* * *}$ \\
\hline $\operatorname{ROS}_{\mathrm{t}+1}$ & & -0.00495 & \\
\hline $\operatorname{ROS}_{t}$ & $-0.02200^{* * *}$ & & \\
\hline $\mathrm{ROE}_{\mathrm{t}+2}$ & & & 0.00045 \\
\hline $\mathrm{ROE}_{\mathrm{t}+1}$ & & -0.00067 & \\
\hline $\mathrm{ROE}_{t}$ & $-0.00218 * *$ & & \\
\hline Micro & $0.13745^{* *}$ & -0.01191 & 0.01145 \\
\hline
\end{tabular}




\begin{tabular}{|c|c|c|c|}
\hline Small & 0.06924 & -0.05128 & 0.00426 \\
\hline Unemployment rate $_{t+2}$ & & & $0.057567 * * *$ \\
\hline Unemployment rate $_{t+1}$ & & -0.02989 & \\
\hline Unemployment rate $_{\mathrm{t}}$ & $0.03573 * * *$ & & \\
\hline $\mathrm{GDP}_{\mathrm{t}+2}$ & & & 0.00001 \\
\hline $\mathrm{GDP}_{\mathrm{t}+1}$ & & -0.00002 & \\
\hline $\mathrm{GDP}_{\mathrm{t}}$ & 0.00002 & & \\
\hline Adjusted R-squared & 0.17095 & 0.15824 & 0.12339 \\
\hline Obs. & 400 & 400 & 400 \\
\hline
\end{tabular}

Note. The table reports the estimation of the $\Delta$ Score 2 in the year $t$ (when CGF issued the guarantee), $t+1$ (after one year) and $t+2$ (after two years). The significance is expressed with one, two or three asterisks, i.e. the rejection of the hypothesis of values equivalent to 0 with a probability level equal to $10 \%, 5 \%$ or $1 \%$.

Tables 7, 8 and 9 confirm the results over the whole period. The change in scores during the period from $t-1$ to $t+2$ is mainly due to the liquidity, solvency and profitability of firms. Firms showing lower liquidity, solvency and profitability are characterized by a higher probability of default. The geographical area in which SMEs operate has no clear effect on the probability of default over time. We also find evidence that the lower the guaranteed amount and the smaller the size of the company, the greater the probability of default. Finally, we again find that the type of CGF intervention affects the probability of default of SMEs over time, or in other words, counter-guaranteed loans are less risky.

In order to verify whether the new CGF economic evaluation method is more accurate and forward-looking than the previous one for estimating SME default risk, we compare the CGF pre-reform and post-reform scores in the year $t$ (i.e. when CGF issued the guarantee to the SMEs in our sample). This comparison is made considering only the economic-financial module. Results are reported in Table 10.

Table 10. CGF pre-reform and post-reform scores (year $t$ )

\begin{tabular}{lllll}
\hline Probability of default & \multicolumn{2}{l}{ Pre-reform score } & \multicolumn{2}{l}{ Post-reform score } \\
\hline level & n. operations & $\%$ & n. operations & $\%$ \\
High & 34 & $8.50 \%$ & 153 & $38.25 \%$ \\
Medium & 44 & $11.00 \%$ & 138 & $35.25 \%$ \\
Low & 300 & $75.00 \%$ & 98 & $24.50 \%$ \\
n.a. & 22 & $5.50 \%$ & 8 & $2.00 \%$ \\
Total & 400 & $100 \%$ & 400 & $100 \%$ \\
\hline
\end{tabular}

Source: Authors' elaborations.

Table 10 shows that the post-reform scores determine an increase in the percentage of manufacturing SMEs in our sample characterized by a high and medium level of probability of default, while scores are lower for SMEs characterized by a low default probability. In order to investigate the issue further, we observe the trend of scores during the period from $t-1$ to $t+2$. Tables 11 and 12 report the results for the whole sample, counter guarantees and direct guarantees and micro, small and medium firms respectively.

Table 11. Trend of scores (from $t-1$ to $\mathrm{t}+2$ )

\begin{tabular}{llllllllllllll}
\hline \multirow{2}{*}{ Score } & \multicolumn{3}{l}{ Whole sample } & \multicolumn{4}{c}{ Counterguarantee } & \multicolumn{5}{c}{ Direct guarantee } \\
\cline { 2 - 13 } & $t-1$ & $t$ & $t+1$ & $t+2$ & $t-1$ & $t$ & $t+1$ & $t+2$ & $t-1$ & $t$ & $t+1$ & $t+2$ \\
Z-score & 1.27 & 1.26 & 1.03 & 0.33 & 1.26 & 1.23 & 1.00 & 0.29 & 1.27 & 1.26 & 1.03 & 0.33 \\
Score 1 & 9.82 & 9.45 & 9.12 & 9.07 & 9.82 & 9.44 & 9.10 & 9.06 & 9.82 & 9.46 & 9.11 & 9.07 \\
Score 2 & -3.12 & -3.23 & -3.10 & -3.13 & -3.13 & -3.23 & -3.10 & -3.12 & -3.12 & -3.23 & -3.10 & -3.13 \\
\hline
\end{tabular}

Source: Authors elaborations. The sample includes 400 operations, equally divided between counter guarantees and direct guarantees. 
Table 12. Trend of scores (from $t-1$ to $\mathrm{t}+2$ )

\begin{tabular}{llllllllllllll}
\hline \multirow{2}{*}{ Score } & \multicolumn{1}{l}{ Micro } & \multicolumn{1}{c}{ Small } & \multicolumn{1}{c}{ Medium } \\
\cline { 2 - 15 } & $t-1$ & $t$ & $t+1$ & $t+2$ & $t-1$ & $t$ & $t+1$ & $t+2$ & $t-1$ & $t$ & $t+1$ & $t+2$ \\
Z-score & 1.32 & 1.25 & 1.20 & 0.51 & 1.18 & 1.17 & 0.82 & -0.03 & 1.61 & 1.77 & 1.88 & 1.91 \\
Score 1 & 9.05 & 9.19 & 9.01 & 8.86 & 9.93 & 9.36 & 8.92 & 8.90 & 10.65 & 10.44 & 10.37 & 10.42 \\
Score 2 & -2.79 & -2.96 & -2.97 & -3.02 & -3.13 & -3.22 & -3.02 & -3.02 & -3.66 & -3.78 & -3.74 & -3.85 \\
\hline
\end{tabular}

Source: Authors' elaborations. The whole sample includes 400 operations, of which 84 concern micro firms, 269 concern small firms and 47 concern medium firms.

As shown in Table 10, most companies are rated at low risk by the pre-reform model, but looking at the Z"-score and Score 1 over time, a sharp deterioration can often be seen. Furthermore, Score 1, on the basis of which the guarantee was made to the companies, falls steadily over time, especially for direct guaranteed and micro and small enterprises.

On the other hand, the post-reform model (i.e. Score 2) classifies about three-quarters of companies belonging to the sample as medium-high risk companies (Table 10). Tables 11 and 12 show that the new model, which measures the default risk more severely at an early stage, maintains more constant evaluations over time.

\section{Discussion}

Our results show that when the probability of default is approximated by the change in Z"-score during the period from $t-1$ to $t+2$, firms showing lower liquidity, solvency and profitability are characterized by a greater worsening of probability of default. On the other hand, when the probability of default is approximated by the change in the pre-reform score over time, only the solvency level of SMEs or, in other terms, the quality of their financial structure, is significant. We therefore find an answer to our first research hypothesis: the pre-reform CGFs evaluation method is partially consistent with Z"-score.

When we consider the change in the post-reform score during the period from $t-1$ to $t+2$, we find that ROS and $\mathrm{ROE}$ and the debt to equity ratio are significant. In other terms, with regard to variables relating to specific firms' characteristics, we note a greater consistency between the post-reform CGF score and the Z"-score, one of the most recognized model in the distress prediction literature.

In light of the recent CGF reform, we felt it was interesting to assess the guaranteed SMEs included in our sample by the new model. We find that the percentage of firms characterized by a low probability of default decreases. This may be an important result because of the potential risk of losses of public funds when risky SMEs are guaranteed.

Moreover, since our results show a more constant trend of the post-reform score over time, it seems that the new CGF model also has a better forecasting capacity, and should thus be considered more effective in assessing the creditworthiness of SMEs. Our second hypothesis, that "The predictive capability of CGF methodology is higher in the post-reform credit rating model than the previous model" is thus confirmed.

Among the variables we considered in our analysis, the amount guaranteed in relation to the loan amount is relevant. Since we find that the probability of default approximated by the CGF scores is low when the amount guaranteed is greater, we suggest that coverage ratios over a certain threshold are likely to be effective in lessening obstacles faced by SMEs when seeking external financing funds (Boschi et al., 2014). In other words, a firm may find it easier to obtain additional bank financing when providing collaterals considered as adequate.

Our findings also show that the probability of default on exposures covered by a mutual guarantee institution and counter-guaranteed by the CGF is lower than that of loans granted by a bank and directly guaranteed by CGF. Therefore, our third research hypothesis, that "the probability of default of loans directly guaranteed by CGF is lower than the probability of default of counter-guaranteed loans", is not confirmed by our results. Nevertheless, our results confirm findings by one strand of literature which highlights the advantages of counter-guarantee schemes and the benefits brought by a mutual guarantee institution.

Since direct guarantees are riskier than the counter guarantees, they may be more closely monitored by the CGF and this may have effects on bank behaviour. The European Central Bank (ECB) in its recent Asset Quality Review in fact called for greater supervision of banks, in particular, enhancement of transparency on bank exposures, including the adequacy of asset and collateral valuations (European Central Bank, 2018b). In order to assess the financial health of banks and check whether they adequately capture cases of forbearance, the ECB requires banks to define a perimeter for selectable debtors. This means that financial institutions have to select 
borrowers according to their economic and financial situation, among other factors. The ECB identifies the ratio between total debt and total EBITDA (Earnings Before Interest, Taxes, Depreciation and Amortization) of debtors as one of the potential useful indicators of debt service capacity, and thus includes the following firm characteristics in asset quality assessment: firm financial structure, firm profitability, firm solvency and, obviously, firm liquidity. If SMEs need to approach the bank lending channel, they must have specific economic-financial characteristics, including high levels of liquidity, solvency and profitability, which are the same characteristics which emerged as significant for receiving a state guarantee from the CGF.

\section{Conclusions and Implications}

The paper investigates CGF guarantees to SMEs. Because there are different types of CGF intervention, the analysis distinguishes between the channels of direct guarantee to banks and counter-guarantee to mutual guarantee institutions (Confidi). In particular, we verify whether the scores calculated using CGF assessment methodologies, developed before and after its recent reform, are consistent with one of the best-known distress prediction models, the Altman Z'-score. We verify whether the probability of default of the guaranteed SMEs differs according to the type of CGF intervention, as well as according to liquidity, solvency and profitability levels of the firms. Finally, we test whether the new CGF assessment method is more effective than the previous one for assessing the creditworthiness of SMEs in the medium term, and whether it obtains a score more consistent with the financial and economic equilibrium of SMEs over time, and able to forecast the future probability of default of guaranteed SMEs.

The analysis focuses on the manufacturing sector, the economic sector which obtained most guarantees in recent years. Our final sample includes 400 operations, of which 84 concerning micro firms, 269 concerning small firms, and 47 concerning medium firms. The operations included in our sample represent the universe of guarantees made by the CGF to manufacturing SMEs during the period from the third quarter 2012 to the second quarter 2018.

Our main findings are the following. The pre-reform CGF scores are able to capture certain financial ratios affecting SME default probability (e.g. debt to equity ratio and ROS), as confirmed by comparison with Z"-scores. Other variables are statistically related to the probability of default measured by the CGF model, such as the geographical area of the company, and the amount guaranteed. In particular, the greater the amount guaranteed in relation to total loan amount, the lower the probability of default. This implies that an adequate coverage ratio may lessen obstacles faced by SMEs when seeking external financing resources.

The post-reform CGF scores are more consistent with the Z"-score: the change in scores during the whole period from $t-1$ to $t+2$ is mainly due to the solvency (i.e. debt to equity ratio) and profitability (i.e. ROS and ROE) levels of the guaranteed firms. Our findings show greater effectiveness of the new CGF evaluation model, which implies that the Italian public guarantee scheme should be more sustainable in the near future.

Our paper contributes to shedding light on the CGF and its workings. We find that compared to the pre-2018 scores, the new CGF scores at time $t$ (i.e. guarantee year) show values which would have led to a more negative evaluation of firms.

Indeed, applying the pre-2018 CGF model during the years immediately following the provision of the guarantee gives deteriorating scores. In other words, the creditworthiness of the companies guaranteed decreases over time. This is not entirely consistent with the initial assessment, which classified most of guaranteed companies as "low-risk". The post-2018 model seems to make a more accurate initial assessment of creditworthiness and shows greater stability at one and two years from the year when CGF issued the guarantee. In other words, the recently enriched and improved scoring models used by the CGF appear to provide a more effective means for allocation of public funds, because they show better forecasting capacity.

Our results also demonstrate that the probability of default of SMEs guaranteed differs according to the type of intervention made by the CGF. In particular, we find that the default probability of counter-guaranteed loans is lower than that of loans directly guaranteed by CGF.

These results are significant, but certain weaknesses in the study need to be noted. The first is that we describe only one sector, although the manufacturing sector yields a universe of homogeneous firms which obtained guarantees. It is moreover the sector with the highest numbers of applications accepted and firms guaranteed in recent years (CGF, 2019). Another limitation of our study is that we were unable to use information and data from the Italian Central Credit Register and Credit Bureau, which would have made it possible to make an overall assessment of SME creditworthiness in line with the new CGF model.

Our analysis has many practical implications. The main results show that the post-reform model should make it 
possible to limit interventions in firms characterized by higher levels of risk, and thereby indirectly affect the behaviour of lenders and first-level guarantors. Since our findings show a higher level of risk for direct guarantees, we expect that the CGF scoring model should monitor the granting of this kind of guarantee application to SMEs, which in turn should affect bank behaviour. It follows that if SMEs want to gain access to both the bank lending channel and public guarantees, their management needs to aim for adequate levels of these economic and financial aspects.

Appropriate design of the CGF and its methodologies for selecting beneficiaries is crucial for controlling moral hazard in financial institutions and ensuring the financial sustainability of public intervention. Applying a more forward-looking methodology should make it possible to make a more sound selection of the beneficiaries of CGF guarantees. This does not mean that the CGF will reduce the number of firms guaranteed or loans covered. The CGF has three other main levers to rationalize its intervention according to the level of risk of the borrower: (1) modulating prices of guarantees; (2) modulating the maximum amount of the guarantee; (3) modulating the maximum ratio between the amount of the guarantee and the total loan (coverage ratio). Our study suggests that these levers enable the CGF to fine tune public resource allocation in order to reduce opportunistic behaviours of financial institutions, and at the same time, reward the most virtuous intermediaries for managing their portfolios to limit default rates. We expect that the greater complexity of the new model will improve the quality of initial selection of the SMEs, increasing the effectiveness of the Italian guarantee program.

\section{References}

ADB-OECD. (2014). Study on Enhancing Financial Accessibility for SMEs. Lessons from recent crises. https://www.oecd.org/cfe/smes/adb-oecd-study-enhancing-financial-accessibility-smes.pdf. Accessed on $01 / 02 / 2019$.

AECM. (2010). Guarantees and the Recovery: the impact of anti-crisis guarantee measures. Secretariat General AECM Brussels (Belgium). https://aecm.eu/wp-content/uploads/2015/07/report-on-performance-of-anti-crisis-guarantee-measures1.pdf. Accessed on 1/01/02/2019

Altman, E. I. (1968). Financial Ratios. Discriminant Analysis and the Prediction of Corporate Bankruptcy. The Journal of Finance, 23(4), 589-609. https://doi.org/10.1111/j.1540-6261.1968.tb00843.x

Altman, E. I. (1983). Corporate Financial Distress. New York: Wiley Interscience.

Altman, E. I., Hartzell, J., \& Peck, M. (1995). Emerging Markets Corporate Bonds: A Scoring System. Salomon Brothers Inc. New York, and in Levich, R. and Mei, J.P. "The Future of Emerging Market Flaws". Kluwer.

Altman, E. I. (2002). Revisiting Credit Scoring Models in a Basel 2 Environment. In M. Ong, Credit Rating: Methodologies. Rationale and Default Risk. London Risk Book.

Altman, E. I., \& Hotchkiss, E. (2006). Corporate Financial Distress \& Bankruptcy. Hoboken, NJ: J. Wiley \& Sons, Inc.

Altman, E. I., Danovi, A., \& Falini, A. (2013). Z-Score Models' Application to Italian Companies Subject to Extraordinary Administration. Journal of Applied Finance, 23(1), 128-137.

Arping, S., Loranth, G., \& Morrison, A. D. (2010). Public initiatives to support entrepreneurs: Credit guarantees versus co-funding. Journal of Financial Stability, 6(1), 26-35. https://doi.org/10.1016/j.jfs.2009.05.009

Asdrubali, P., \& Signore, S. (2015). The Economic Impact of EU Guarantees on Credit to SMEs. Evidence from CESEE Countries. EIF Research \& Market Analysis. Working Paper n. 29, July.

Aziz, A., Emanuel, D. C., \& Lawson, G. H. (1988). Bankruptcy Prediction - An Investigation of Cash Flow Based Models. Journal of Management Studies, 25(5), 419-437. https://doi.org/10.1111/j.1467-6486.1988.tb00708.x

Banca, d'Italia. (2017). L'economia delle regioni italiane nel 2016. Rapporto annuale N. 22.

Banca, D. M., \& Medio, C. C. (2018). Specifiche tecniche per il calcolo della probabilità di inadempimento ai sensi del nuovo modello di valutazione del Fondo.

Bartoli, F., Ferri, G., Murro, P., \& Rotondi, Z. (2013). Bank-firm relations and the role of Mutual Guarantee Intitutions at the peak of the crisis. Journal of Financial Stability, 9(1), 90-104. https://doi.org/10.1016/j.jfs.2012.03.003

Beaver, W. H. (1966). Financial Ratios as Predictors of Failure. Empirical Research in Accounting: Selected Studies. Journal of Accounting Research, 5, 71-111. http://dx.doi.org/10.2307/2490171 
Beck, T., Deminguç-Kunt, A., Laeven, L., \& Maksimovic, V. (2006). The determinants of financing obstacles. Journal of International Money and Finance, 25(6), 932-952.

Beck, T., \& Deminguç-Kunt, A. (2006). Small and Medium-Size Enterprises: Access to Finance as a Growth Contraint. Journal of Banking and Finance, 30(11), 2931-2943. https://doi.org/10.1016/j.jbankfin.2006.05.009

Beck, T., Klapper, L., \& Mendoza, J. (2008). The typology of partial credit guarantee funds around the world. Policy research working paper n. 4771, The World Bank. https://openknowledge.worldbank.org/bitstream/handle/10986/6387/ WPS4771.pdf?sequence=1.

Bellovary, J., Giacomino D., \& Akers M. (2007). A Review of Bankruptcy Prediction Studies: 1930 to Present. Journal of Financial Education, 33, 1-42.

Berger, A. N., \& Udell, G. F. (2006). A More Complete Conceptual Framework for SME Finance. Journal of Banking and Finance, 30/11, 2945-2966. https://doi.org/10.1016/j.jbankfin.2006.05.008

Boot, A. W. A., \& Thakor, A. V. (1994). Moral hazard and secured lending in an infinitely repeated credit market game. International Economic Review, 35, 899-917. https://doi.org/10.2307/2527003

Boschi, M., Girardi, A., \& Ventura, M. (2014). Partial credit guarantees and SMEs financing. Journal of Financial Stability, 15, 182-194. https://doi.org/10.1016/j.jfs.2014.09.007

Bubb, R., \& Kaufman, A. (2009). Securitization and moral hazard: evidence from a lender cut off rule. Public policy discussion papers, Federal Reserve Bank of Boston, N. 09.5. https://www.bostonfed.org/publications/public-policy-discussion-paper/2009/securitization-and-moral-hazar d-evidence-from-a-lender-cutoff-rule.aspx. Accessed on 01/02/2019.

Cardone-Riportella, C., Trujillo-Ponce, A., \& Briozzo, A. (2013). Analyzing the Role of Mutual Guarantee Societies on Bank Capital Requirements for Small and Medium-Sized Enterprises. Journal of Economic Policy Reform, 16/2, 142-159. https://doi.org/10.1080/17487870.2013.801317

CGF - Central Guarantee Fund. (2019). Report al $30 \quad$ giugno 2019. https://www.fondidigaranzia.it/numeri-del-fondo/

CGF - Central Guarantee Fund. (2015). Il Fondo di garanzia per le PMI - Disposizioni operative.

Columba, F., Gambacorta, L., \& Mistrulli, P. E. (2010). Mutual guarantee institutions and small business finance. Journal of Financial Stability, 6, 45-54.

De Jong, A., Kabir, R., \& Nguyen, T. (2008). Capital structure around the world: the roles of firm and country specific determinants. Journal of Banking and Finance, 32/9, 1954-1969. https://doi.org/10.1016/j.jbankfin.2007.12.034

Edmister, R. O. (1972). An Empirical Test of Financial Ratio Analysis for Small Business Failure Prediction. Journal of Financial and Quantitative Analysis, 7/2, 1477-1493. https://doi.org/10.2307/2329929

Erzegovesi, L. (2009), Verso un nuovo modello di equilibrio gestionale dei consorzi fidi. In M. Comana (by), Banca, Credito e Rischi. Saggi in onore di Tancredi Bianchi, Vol. 2. Roma: Bancaria Editrice, 115-132.

European Commission. (2005). Guarantees and Mutual Guarantees. Report to the Commission by an Independent Expert Group. January.

European Central Bank - ECB. (2018a). Survey on the Access to Finance of Enterprises in the euro area. Retrieved

from https://www.ecb.europa.eu/stats/accesstofinancesofenterprises/pdf/ecb.accesstofinancesmallmediumsizeden terprises201806.en.pdf?f39a5afa92e40c051dfb5dde764306ba. Accessed on 01/02/2019.

European Central Bank - ECB. (2018b). Asset Quality Review. Retrieved from https://www.bankingsupervision.europa.eu/ecb/pub/pdf/ssm.assetqualityreviewmanual201806.en.pdf

European Investment Fund (2014). European small business finance outlook. Working paper 26. http://www.eif.org/news_centre/publications/EIF_Working_Paper_2014_26.htm (accessed on May 20, 2019).

Ferri, G., \& Messori, M. (2000). Bank-firm relationships and allocative efficiency in Northeastern and Central Italy and in the South. Journal of Banking \& Finance, 24/6, 1067-1095.

FitzPatrick, P. J. (1932). A Comparison of Ratios of Successful Industrial Enterprises with Those of Failed Companies. In The Certified Public Accountant. 
Gai, L., Rossi, F., \& Catelani, E. (2010). Public policies and venture capital in supporting SMEs: an economic comparison of available instruments. Strategic Change, 19(7-8), 293-302. https://doi.org/10.1002/jsc.877

Gai, L., \& Ielasi, F. (2014). Operational drivers affecting credit risk of mutual guarantee institutions. The Journal of Risk Finance, 15(3), 275-293. https://doi.org/10.1108/JRF-12-2013-0087

Hall, G., Hutchinson, P, \& Michaelas, N. (2004). Determinants of the capital structure of European SMEs. Journal of Business Finance and Accounting 31(5-6), 711-728. https://doi.org/10.1111/j.0306-686X.2004.00554.x

Hartman-Glaser, B., Piskorski, T., \& Tchistyi, A. (2012). Optimal securitizazion with moral hazard. Journal of Financial Economics, 104(1), 186-202. https://doi.org/10.1016/j.jfineco.2011.12.007

Hillegeist, S., Cram, D., Keating, E., \& Lundstedt, K. (2004). Assessing the Probability of Bankruptcy. Review of Accounting Studies, 9(1), 5-34.

Holton, S., McCann, F., Prendergast, K., \& Purdue, D. (2013). Policy measures to improve access to credit for SMEs: a survey. Quarterly Bulletin Articles, Central Bank of Ireland, n. 4, October, 91-110.

Honohan, P. (2008). Partial credit guarantees: principles and practice. Journal of Financial Stability, 6(1), 1-9. https://doi.org/10.1016/j.jfs.2009.05.008

Hudon, M. (2009). Should access to credit be a right? Journal of Business Ethics, 84, 17-28.

Jemenez, G., \& Saurina, J. (2004). Collateral, type of lender and relationship banking as determinants of credit risk. Journal of Banking and Finance, 28/9, 2192-2212. https://doi.org/10.1016/j.jbankfin.2003.09.002

Johnson, C. G. (1970). Ratio Analysis and the Prediction of Firm Failure. The Journal of Finance, 25(5), 1166-1168. https://doi.org/10.2307/2325590

Korosteleva, J., \& Mickiewicz, T. (2011). Start-Up Financing in the Age of Globalization. Emerging Markets Finance and Trade, 47(3), 23-49. https://doi.org/10.2753/REE1540-496X470302

KPMG. (2012). Credit access guarantees: a public asset between the State and the market. International survey on guarantee market players. KPMG Advisory. https:/assets.kpmg/content/dam/kpmg/pdf/2013/06/KPMG-Credit-access-guarantees-public-asset-betweenState-Market.pdf. Accessed on 01/02/2019.

Lawless, M., O’Connel, B., \& O’Toole, C. (2015). Financial structure and diversification of European firms. Applied Economics, 47(23), 2379-2398. https://doi.org/10.1080/00036846.2015.1005829

Leone, P., \& Vento, G. A. (2012). Credit guarantee institutions and SME finance. London: Palgrave Macmillan.

Levitsky, J. (1997). Credit guarantee schemes for SMEs - an international review. Small Enterprise Development, 8(2), 4-17.

Libby, R. (1995). Accounting Ratios and the Prediction of Failure: Some Behavioral Evidence. Journal of Accounting Research, 13(1), 150-161. https://doi.org/10.2307/2490653

Mistrulli, P., \& Vacca, V. (2011). Mutual guarantee institutions and small business credit during the crisis. Occasional paper 105. Bank of Italy.

OECD. (2016). Financing SMEs and Entrepreneurs $2016-$ An OECD Scoreboard. https://www.oecd-ilibrary.org/industry-and-services/financing-smes-and-entrepreneurs-2016_fin_sme_ent2016-en

OECD. (2013). Financing SMEs and Entrepreneurs 2013: an OECD scoreboard. Final paper. https://www.oecd-ilibrary.org/industry-and-services/financing-smes-and-entrepreneurs-2013_fin_sme_ent2013-en

Ohlson, J. (1980). Financial Ratios and the Probabilistic Prediction of Bankruptcy. Journal of Accounting Research, 18(1), 109-131. https://doi.org/10.2307/2490395

Psillaki, M., \& Daskalakis, N. (2009). Are the determinants of capital structure country or firm specific? Small Business Economics, 33(3), 319-333.

Ramser, J. R., \& Foster, L. O. (1931). A Demonstration of Ratio Analysis. Bureau of Business Research Bulletin, 40.

Riding, A. L., \& Haines, G. Jr. (2001). Loan Guarantees: cost of default and benefits to small firms. Journal of Business Venturing, 16(6), 595-612. https://doi.org/10.1016/S0883-9026(00)00050-1 
Riding, A., Madill, J., \& Haines, G. Jr. (2007). Incrementality of SME loan guarantees. Small Business Economics, 29(1-2), 47-61.

Shumway, T. (2002). Forecasting Bankruptcy More Accurately: A Simple Hazard Model. Journal of Business, 74/1, 101-124. https://doi.org/10.1086/209665

Smith, F. R., \& Winakor A. H. (1935). Changes in Financial Structure of Unsuccessful Corporations. Bureau of Business Research Bulletin. University of Illinois Press.

Tamari, M. (1966). Financial Ratios as a Means of Forecasting Bankruptcy. Management International Review, $6(4), 15-21$.

Zaho, J. (2008). Research on the Financing of Small and Medium Enterprises. International Journal of Business and Management, 3(11), 171-174.

Zhang, P., \& Ye, Y. (2010). Study on the Effective Operation Model of Credit Guarantee system for small and medium enterprises in China. International Journal of Business and Management, 5(9), 99-106.

Zecchini, S., \& Ventura, M. (2009). The impact of public guarantees on credit to SMEs. Small Business Economics, 32(2), 191-206.

\section{Notes}

Note 1. SMEs are defined as having fewer than 250 employees. SMEs should have an annual turnover of up to EUR $50 \mathrm{~m}$ or a balance sheet total of no more than EUR $43 \mathrm{~m}$.

Note 2. In 2017, CGF approved around 120,000 guarantee applications submitted by 78,000 enterprises, which had access to EUR 17.5 billion of financing. From the start of operations to the end of July 2018, CGF approved more than 828,000 applications by around 400,000 enterprises, equaling an overall amount of EUR 78.8 billion in issued guarantees (CGF - Central Guarantee Fund, 2015).

Note 3. For an overview of bankruptcy predictions from 1930 to 2002, see Bellovary et al. (2007).

Note 4. Descriptive statistics for years $t-1, t+1$ and $t+2$ are available on request.

\section{Copyrights}

Copyright for this article is retained by the author(s), with first publication rights granted to the journal.

This is an open-access article distributed under the terms and conditions of the Creative Commons Attribution license (http://creativecommons.org/licenses/by/4.0/). 